Volume 3

Issue 2 -- Infectious Disease

Article 2

4-22-2016

\title{
Epidemiology Crucial to Cracking Elizabethkingia Crisis
}

Angela Tonozzi

Follow this and additional works at: https://aah.org/jpcrr

Part of the Bacteria Commons, Bacterial Infections and Mycoses Commons, Community Health and Preventive Medicine Commons, Epidemiology Commons, and the Infectious Disease Commons

\section{Recommended Citation}

Tonozzi A. Epidemiology crucial to cracking Elizabethkingia crisis. J Patient Cent Res Rev. 2016;3:64-65. doi: 10.17294/2330-0698.1266

Published quarterly by Midwest-based health system Advocate Aurora Health and indexed in PubMed Central, the Journal of Patient-Centered Research and Reviews (JPCRR) is an open access, peer-reviewed medical journal focused on disseminating scholarly works devoted to improving patient-centered care practices, health outcomes, and the patient experience. 


\title{
Epidemiology Crucial to Cracking Elizabethkingia Crisis
}

\author{
Angela Tonozzi, MD, MS | Editorial \\ Infection Prevention, Aurora Health Care, Milwaukee, WI
}

In 1854, a cholera epidemic struck London, England. John Snow, a local physician and researcher, was focused on determining the source of the illness. He dismissed the popular thought of the time that infectious diseases were caused by "miasmas," the inhaled contaminated vapors or gases that were thought to arise from sewers, garbage dumps and other less appealing areas. Snow's investigations led to a theory that the source of infection was actually germs in the public water ingested by patients, thus causing the digestive symptoms of the disease. He tested this theory by speaking with the inhabitants of neighborhoods in which cholera hit, mapping the cases of disease and linking the cases to water pumps that supplied the public water to these neighborhoods. ${ }^{1}$

This innovative scientific approach came to be called the epidemiologic triangle (Figure 1). ${ }^{2}$ The three corners of the triangle represent the agent, the environment and the host. The agent is the microbe that causes the disease. The environment is made up of the external factors that cause or allow disease transmission. The host is the person or organism that harbors the disease. In Snow's cholera investigation, the agent was the bacteria Vibrio cholera, the environment was the contaminated water from public water pumps, and the host was one who drank the contaminated water.

Snow is now considered the father of modern day epidemiology, as the principles and processes he established to halt communicable disease transmission continue to be used in present-day epidemiologic investigations. Of most recent note is the outbreak of infections in Wisconsin residents caused by Elizabethkingia anophelis.

Correspondence: Angela Tonozzi, MD, MS,

12500 W. Bluemound Road, \#203, Elm Grove, WI, 53122,

T: 262-787-2754, F: 262-787-2788,

Email: angela.tonozzi@aurora.org

Elizabethkingia are bacteria that are ubiquitous in nature (i.e. present in most soil and water) but rarely reported to cause infections in humans. Case studies have reported outbreaks from Elizabethkingia spp. in health care settings, ${ }^{3-6}$ yet the contemporary situation in Wisconsin differs from these reports on several fronts. For one, the outbreak as described by Moore et al. occurred in one health care facility. ${ }^{3}$ In fact, the patients were all located in one unit within the facility. Following environmental sampling cultures, the source of infection was concluded to be the water supplied to the critical care unit.

The Elizabethkingia strain that is causing disease in Wisconsin is more far-reaching. Patients live in many areas, scattered mostly throughout southern and southeastern Wisconsin, and have presented to numerous and widespread health facilities. Unlike Moore's infected population, many of these patients are arriving at the facility already ill. According to a Wisconsin Department of Health Services memo detailing the outbreak (email received March 18, 2016, from Jeffrey P. Davis, MD, the state's chief medical officer), $60 \%$ of the 52 patients with confirmed diagnosis did have 
some manner of health facility exposure one week prior to culture collection. However, that begs the question: what about the other $40 \%$ ?

Of utmost importance to a health care epidemiologist is defining community-acquired infection versus health facility-associated infection. In this outbreak, it is difficult to categorize these cases. Those presenting to the hospital or clinic ill lead one to think the infection must be community-acquired. However, there have been enough health facility-exposed patients to ask whether that visit to a medical facility contributed to the infection or is simply a confounder. With no known source of the infection to date, this question still remains.

So what do we know? Well, we have learned a good deal about the host. Susceptible hosts appear to be immunocompromised patients - those with malignancy, diabetes, renal insufficiency, alcoholic cirrhosis or on immunosuppressive treatment. Looking at the Elizabethkingia-diagnosed patient population as a whole, it is imagined that many would fit this definition of immunocompromised. But what is it about this crop of 52 cases that made them susceptible?

Looking for similarities among all the patients involves detailed case review and conversations with other health care providers, the patients and families themselves, and with a key collaborator in all this work, public health workers. Public health has access to the cases from all reporting health care facilities, can do environmental sampling of water and products in patient homes, and has more access to people, places and things outside of the realm of health care providers.
Armed with this data, the hope is to find commonalities and theories to test for the source of the infection and the mode of transmission.

Through discussions among public health colleagues, health care providers and local and national authorities, we are finding different avenues to explore and investigate, yet none have elucidated the source of infection or the mode of transmission. Continuing on this path, we continue to report cases, dig deep into each presentation for clues and remain steadfast in our goal to end this outbreak.

In this kind of battle, epidemiologists are our best allies and "the triangle" our best weapon.

\section{References}

1. Johnson S. The Ghost Map: The Story of London's Most Terrifying Epidemic - and How It Changed Science, Cities, and the Modern World. New York, NY: Riverhead Books, 2006.

2. Gordis L. Epidemiology, Third Edition. Philadelphia, PA: Saunders Elsevier, 2004.

3. Moore LS, Owens DS, Jepson A, et al. Waterborne Elizabethkingia meningoseptica in adult critical care. Emerg Infect Dis. 2016;22:9-17. CrossRef

4. Jean SS, Lee WS, Chen FL, Ou TY, Hsueh PR. Elizabethkingia meningoseptica: an important emerging pathogen causing healthcare-associated infections. J Hosp Infect. 2014;86:244-9. CrossRef

5. Chiu CH, Waddingdon M, Greenberg D, Schreckenberger PC, Carnahan AM. Atypical Chryseobacterium meningosepticum and meningitis and sepsis in newborns and the immunocompromised, Taiwan. Emerg Infect Dis. 2000;6: 481-6. CrossRef

6. Weaver KN, Jones RC, Albright R, et al. Acute emergence of Elizabethkingia meningoseptica infection among mechanically ventilated patients in a long-term acute care facility. Infect Control Hosp Epidemiol. 2010;31:54-8. $\underline{\text { CrossRef }}$

(C) 2016 Aurora Health Care, Inc. 